\title{
Design and Performance of Photovoltaic Water Pumping Systems: Comprehensive Review towards a Renewable Strategy for Mozambique
}

\author{
Rosa J. Chilundo ${ }^{1,2 *}$, Urânio S. Mahanjane ${ }^{2}$, Diana Neves ${ }^{3}$ \\ ${ }^{1}$ Faculty of Sciences, Eduardo Mondlane University, Maputo, Mozambique \\ ${ }^{2}$ Higher Technical School, Pedagogical University, Maputo, Mozambique \\ ${ }^{3} \mathrm{IN}+$ Center for Innovation, Technology and Policy Research, Higher Technical Institute, University of Lisbon, Lisbon, Portugal \\ Email: ^rosychilundo@gmail.com
}

How to cite this paper: Chilundo, R.J., Mahanjane, U.S. and Neves, D. (2018) Design and Performance of Photovoltaic Water Pumping Systems: Comprehensive Review towards a Renewable Strategy for Mozambique. Journal of Power and Energy Engineering, 6, 32-63.

https://doi.org/10.4236/jpee.2018.67003

Received: July 10, 2018

Accepted: July 27, 2018

Published: July 30, 2018

Copyright $\odot 2018$ by authors and Scientific Research Publishing Inc. This work is licensed under the Creative Commons Attribution International License (CC BY 4.0).

http://creativecommons.org/licenses/by/4.0/

(c) (†) Open Access

\begin{abstract}
The use of solar photovoltaic (PV) technology for water pumping systems (WPS) has been one of the most popular forms of solar energy application in recent decades in remote and desert areas, as well as in some urban areas. In this article, an advanced literature review on the design and performance of solar technology for water pumping is presented, exploring also the best perspective of transition for the developing countries energy needs. Additionally, this paper intends to analyze the Mozambique's perspective on renewable energy technologies setting the Mozambican scenario regarding photovoltaic water pumping systems (PVWPS) technology with the aim to identifying the main knowledge of PVWPS design and research gap. The results show that the most commonly used configuration of PVWPS technology is direct coupling systems without battery storage. These systems are simple and reliable, mainly used in small-scale pumping for small irrigations and domestic use. The mainly variables that influence the performance of PVWPS are: total dynamic head, quantity of fluid extracted, variation of solar radiation level, PV and motor pump technology. Yet, the efficiency of the PV and overall system does not exceed $10 \%$ and $5 \%$, respectively. Looking at the designing, mathematical models, software-assisted is being predominant. Yet, as research gap, it is possible to understand from different authors that the dynamic nature of the end-use of PVWPS is not explored on methodology design of PVWPS, and the techno-economic optimum system configuration is not always the one that gives the highest annual system efficiency. For the Mozambican's context, PVWPS for irrigation have been expanding slowly but have gained expression since 2013. In turn, static models based on software of
\end{abstract}


pump manufacturers for PVWPS design are the most widely used in Mozambique. In Mozambique, PVWPS match the perspective of different researchers regarding the availability of solar resource, boreholes and amount of water required for irrigation. The adoption of PVWPS is a means of increasing the sustainability of the rural communities.

\section{Keywords}

Photovoltaic Water Pumping Systems, Energy resource

\section{Introduction}

In a world struggling with climate change and global warming, renewable sources of electricity generation are a very important response to climate issues. In addition, they are also a key tool for developing countries, where a significant part of the population does not have access to the conventional electricity network [1]. In Mozambican's case, more than $70 \%$ of the population does not have access to the conventional electricity network [2].

Economists cited by Vann Koppen, Namara and Safilios-Rothschild [3] argue that agriculture is the engine of all economic growth, as a consequence, reduction of poverty throughout history. However, the irrigation process in modern agriculture is still based on the exploitation of fossil fuels [4]. Since agriculture is a vital activity for the maintenance of humanity, the adoption of self-sustaining agricultural production practices using renewable and endogenous energy resources becomes an essential element for the development of communities, either economically and socially [5].

New conversion methods are explored in order to minimize dependence on fossil fuels [6]. Thus, the direct relationship between the availability of renewable resources and water demand for irrigation urges researchers and local stakeholders to analyze the feasibility of WPS. The use of solar photovoltaic (PV) energy technology for water pumping systems (WPS) for irrigation has been one of the most popular forms of solar energy application, in recent decades, in remote and desert areas, as well as in some urban areas [7]. However, the evaluating of availability of solar and water resources before installing any PV system for irrigation is necessary in order to guarantee optimal solutions.

Fedrizzi [8] mentions different PV systems for water pumping developed around the world, and although some PV systems projects need some care and improvement, the number of systems already installed shows that the technology is technically mature (see Section 2.1). Andrade et al. [9] deepen the historical context and refer that these types of systems have been used in massive scale since 1977 in many countries of the world, mainly in developing countries of Africa, Asia and South America.

In Mozambican's context, PVWPS for irrigation have been expanding slowly but have gained expression since 2013 with significant development. The esti- 
mated capacity of PV solar energy installed is $2.250 \mathrm{kWp}$ [10].

The main barriers to the implementation of PVWPS are related to technical aspects, and the sizing models of PVWPS for irrigation are based on estimates of daily water consumption and static models, and in economic aspects, the capital cost of PVWPS is still higher than the traditional system driven by diesel engine, although the operating costs are much lower. As challenges, it is necessary to adopt dynamic models design of PVWPS and policies that favor the massification of the technology and that in a way the systems are financially viable, besides technical measures that collaborate for the best technical use of these systems.

In this article, a comprehensive review of different published scientific papers on the design and performance of solar photovoltaic energy for water pumping systems is made, exploring the best perspective of transition for the developing countries energy needs. The main objective is identifying the main knowledge of PVWPS sizing, research gap and consequent driver for setting the Mozambican scenario regarding PVWPS technology. The article is organized as follows: Section 1 is the research introduction; Section 2 presents the principle of PVWPS, historical background and technology advancement; while in Section 3, an overview of performance analysis research of PVWPS is given; Section 4 explores the design methods of PV water pumping systems; and Section 5 reports the Mozambique's Perspective on Renewable Energy Technologies; while the final conclusions are given in Section 6.

\section{Principle of Photovoltaic Water Pumping Technology-Literature Survey}

WPS can be classified according to the energy source that drives the system. Therefore, five types of pumping systems are considered:

1) Photovoltaic pumping systems;

2) Wind pumping systems;

3) Pumping systems connected to conventional electricity grid;

4) Pumping systems driven by internal combustion engines;

5) Manual pumping systems.

In some cases, because of the intermittent character of some sources or the complexity of each system, hybrid sources can be adopted (a combination of two or more sources).

Solar PV technology applied to WPS is based on conversion of solar energy into electrical energy by solar panels to power a water pump. PV panels are connected to a DC or AC motor that converts the electrical energy received from the panels into mechanical energy and is subsequently converted into hydraulic energy [11]. As Figure 1 describes, the PVWPS generally consist of:

- An area of PV modules mounted on a structure with fixed arrangement or manual/automatic tracking;

- Pumping system (motor-pump), which can be surface mounted, submersible or floating; 

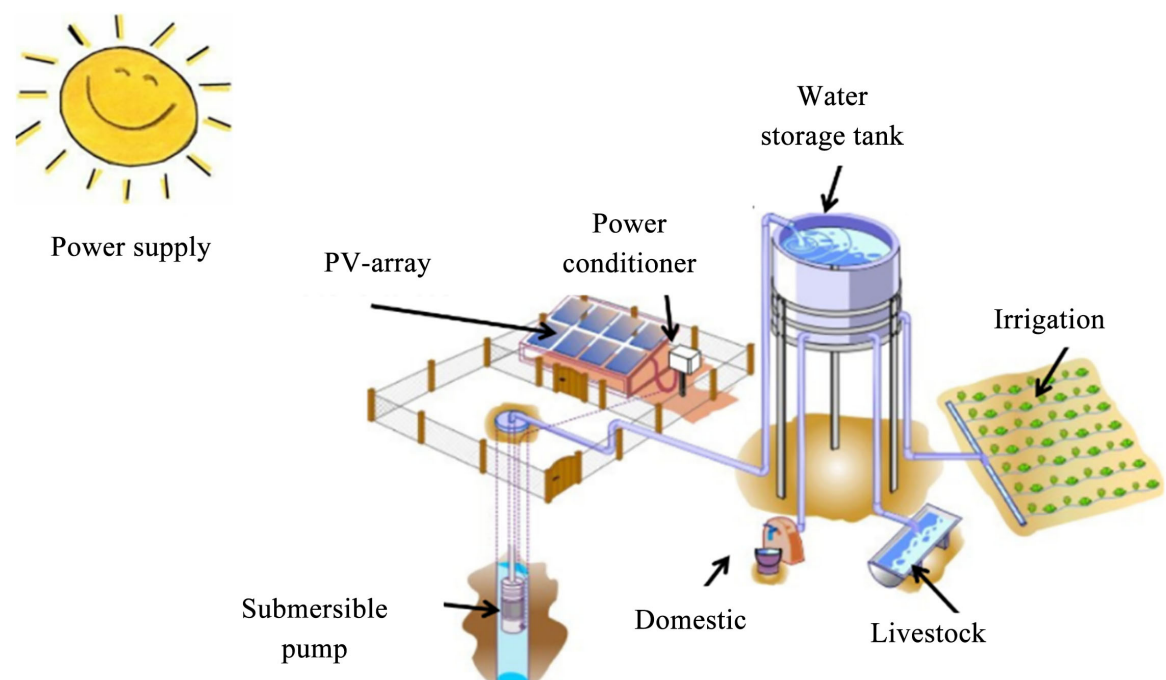

Figure 1. Photovoltaic pumping system ${ }^{1}$.

- Power conditioning system, which generally consists of converter, inverter, controller, etc.; and

- Storage system which may be optional.

\subsection{Historical Background and Technological Advancement}

Solar PV technology for water pumping has been explored over 5 centuries ago. The conversion of solar energy into mechanical or electrical energy for water pumping is used since the 15th century, although the first reported PVWPS was installed in the Soviet Union only in 1964. The maximum power of the PV system installed at that time, to activate the water pump, was $373 \mathrm{~W}$ was developed in France [12].

Initially, solar pumping systems with direct coupling with the water pumps were introduced; however, they presented limitations in the performance of the system, by not operating at the maximum power point of the PV generator. Despite this disadvantage, this type of system is considered to be simple and reliable [13], being also efficient for use in small irrigations [14]. In the last decade, these systems have been improving their performance due to the addition of the maximum power point tracker (MPPT) and control systems [15].

The first generation of PVWPS was characterized by the use of centrifugal pumps driven by direct current (DC) motors and variable frequency alternating current (AC) motors, whose hydraulic efficiency ranges from $25 \%$ to $35 \%$. The second generation of PVWPS considered positive displacement pumps, characterized by low photovoltaic power ( $100 \mathrm{Wp}$ to $400 \mathrm{Wp}$ ) input, low capital cost and hydraulic efficiencies up to 70\% [16]. Currently, the PVWPS of the first and second generation are equipped with electronic control systems, pump speed ${ }^{1}$ Source: Adapted from Arquivo gráfico do Laboratório de Sistemas FVs-IEE/USP (2011). 
and maximum power trackers, to increase the overall system performance [17], whose hydraulic efficiencies reach values of $92 \%$ [18].

\section{Some Projects of Photovoltaic Water Pumping Systems Implemented} around the World

PVWPS for domestic end-users are frequent, however for agricultural production systems there is few systematized information made available. According to EPIA [19], in 2010 there were about 150,000 PV pumping systems installed around the world. Each system had an average PV power of $800 \mathrm{Wp}$, an average manometric height of $60 \mathrm{~m}$ and a flow of $40 \mathrm{~m}^{3} /$ day. In the specific case of Brazil up to 2002, 3.291 PVWPS have been installed, 32 of which were applied directly to agricultural production [20].

Having been identified the potential of PVWPS, numerous initiatives and programs were taken all over the world as a way to spark development in rural areas.

Between 1979 and 1981, a partnership between the United Nations Development Program, World Bank and Intermediate Technology Development Group, carried out a project to evaluate small irrigation PV systems (100 Wp to 300 Wp) used in small agricultural units in Mali, Philippines and Sudan [21]. Furthermore, between 1998 and 2002, the German Cooperation Agency, started the program Photovoltaic Pumping Irrigation Pilot Project, where 90 PVWPS were installed in Brazil, Jordan, Indonesia, Argentina, Philippines and Zimbabwe, prefacing a power of $180 \mathrm{kWp}$ [22]. Additionally, the north Africa was also the target of multiple PVWPS projects: the Solar Regional Program for solar water supply to eight countries in Saharan region, installed 1040 PVWPS with a total output of 1.3 MWp [23]; while 50 PVWPS have been implemented in Morocco with support of European Union, totaling $173 \mathrm{kWp}$, in order to supply drinking water to communities, where part of the water surplus is used for practice of subsistence agriculture [24].

Following several PVWPS installed, Narvarte et al. [25], proposed procurement specifications and testing procedures in order to assure technical quality of these systems. To this end, a quality assurance procedure has been designed and implemented taking into account the common procedures for awarding public funding programs together with the need for a strong commitment from users, which generally constitute an obstacle to the extension of quality assurance and systems sustainability. All these actions were not enough to make the systems self-sustaining, getting the best gain.

\subsection{Solar Energy Opportunities in Mozambique}

The solar market has been expanding slowly but has gained expression since 2009. There are projects and initiatives carried out by the private sector and international cooperation agencies and by the Government through National Energy Fund (FUNAE). It is estimated that the current installed capacity of solar energy in the country is $2.250 \mathrm{kWp}$. In addition to a number of small-scale 
projects, there are two projects in the country for solar power stations in the central and northern regions that come from partnerships between the foreign private sector and government. Furthermore, since 2013, Mozambique has a local solar panel production industry for the local market and at a later stage for the international market [111], with the aim of expanding the electricity grid in the country through alternative and clean sources.

Solar PV technology for water pumping is clean and promising, given the autonomy and abundance of the solar resource in Mozambique with global horizontal plane radiation varying between 1.785 and $2.206 \mathrm{kWh} / \mathrm{m}^{2} /$ year (see Figure 2), values that are comparable to the best regions of the world in this variable. Thus, the implementation of small autonomous systems of electric power generation using solar PV technology appears as part of the solution in centralized and decentralized uses to:

1) Increase the food production and productivity in small agricultural units,

2) Rise incomes of rural, peri-urban and urban households,

3) Create jobs and normal operation of multiple services,

4) Pump water for different purposes, and

5) Develop nightly literacy and education programs for young people and adults (especially women) in places without access to electricity.

Until then, PV solar technology in Mozambique is being used for lighting purposes, charging mobile phones (more in peri-urban and rural areas), pumping water for domestic, electrification of schools, health centers, police stations and district administrations for basic purposes.

\subsection{Photovoltaic Water Pumping Systems Configuration and Design Components}

Figure 3 presents the various types of configurations of PVWPS, either in DC and $\mathrm{AC}$, where the blue boxes represent the types of PV generator configuration, followed by gray color representing the types of power conditioning systems, and finally, the yellow color represents the motor-pump assembly and the possible couplings. The thick blue lines from the PV generator indicate the most used PVWPS configurations.

From Figure 3, it can be observed that the most commonly used motor pumps are asynchronous $\mathrm{AC}$ motor with centrifugal pump, or in alternative an independent excitement DC motor with centrifugal pump, whose generator structure PV is fixed [28]. Tracking PVWPS are more efficient, however they seem to be very expensive compared to fixed systems [29]. The same comparison can be made under the options of power conditioner. DC motors, somehow fit easily into direct-coupled pumping PV systems, for their compatibility with the power generated by the PV generator [30], being mostly implemented for water pumping needs below $7457 \mathrm{~W}$.

Generally, pumps can be classified according to the principle of operation, which can be divided in: dynamic pumps and positive displacement pumps. 
Dynamic pumps operate by developing a high velocity and liquid pressure in a diffusion flow passage. Centrifugal pumps and axial flow pumps are dynamic pumps. Positive displacement pumps operate by forcing a fixed volume of fluid from the inlet pressure section of the pump to the discharge zone of the pump.

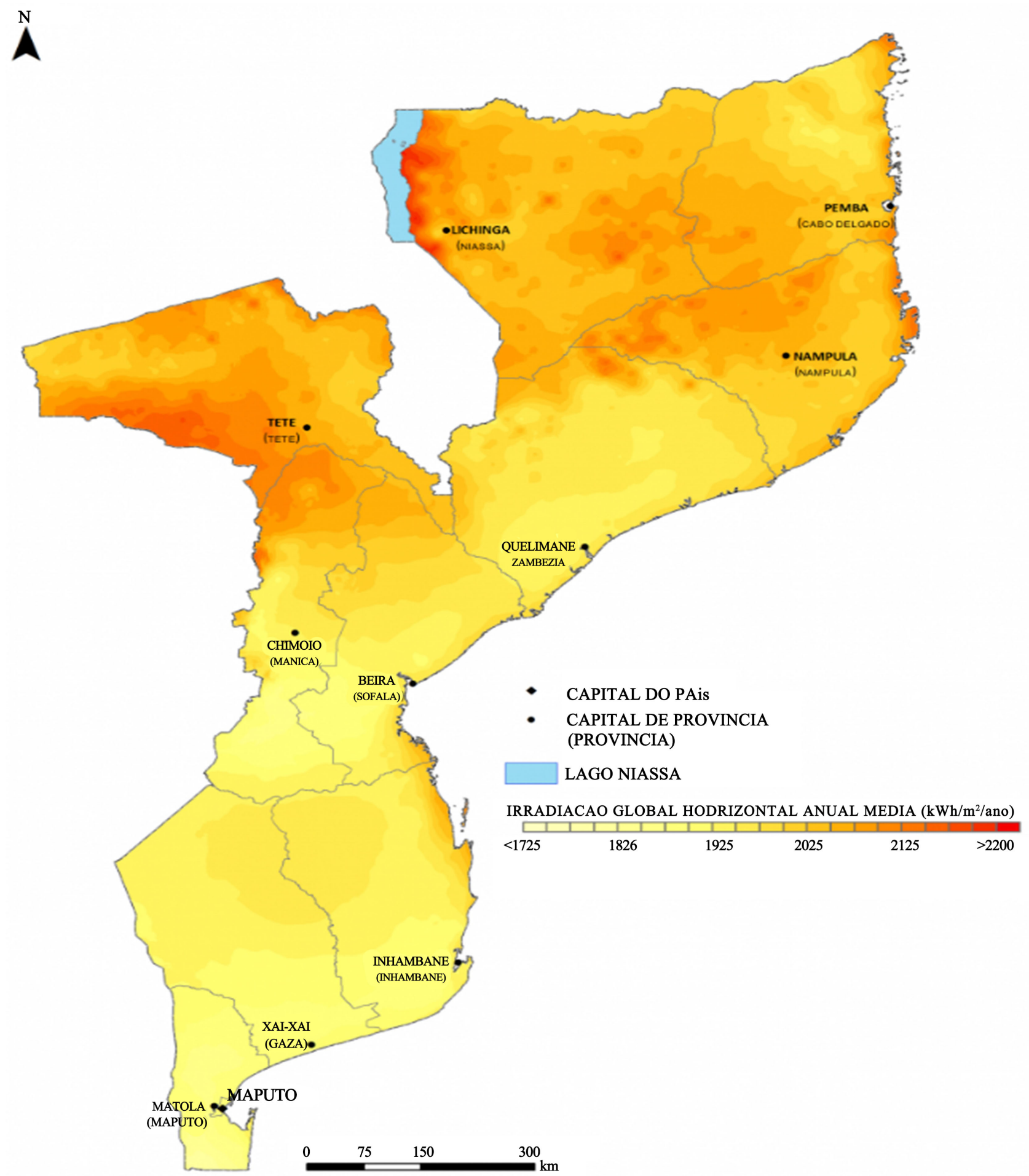

Figure 2. Map of distribution of solar energy in Mozambique [110]. 


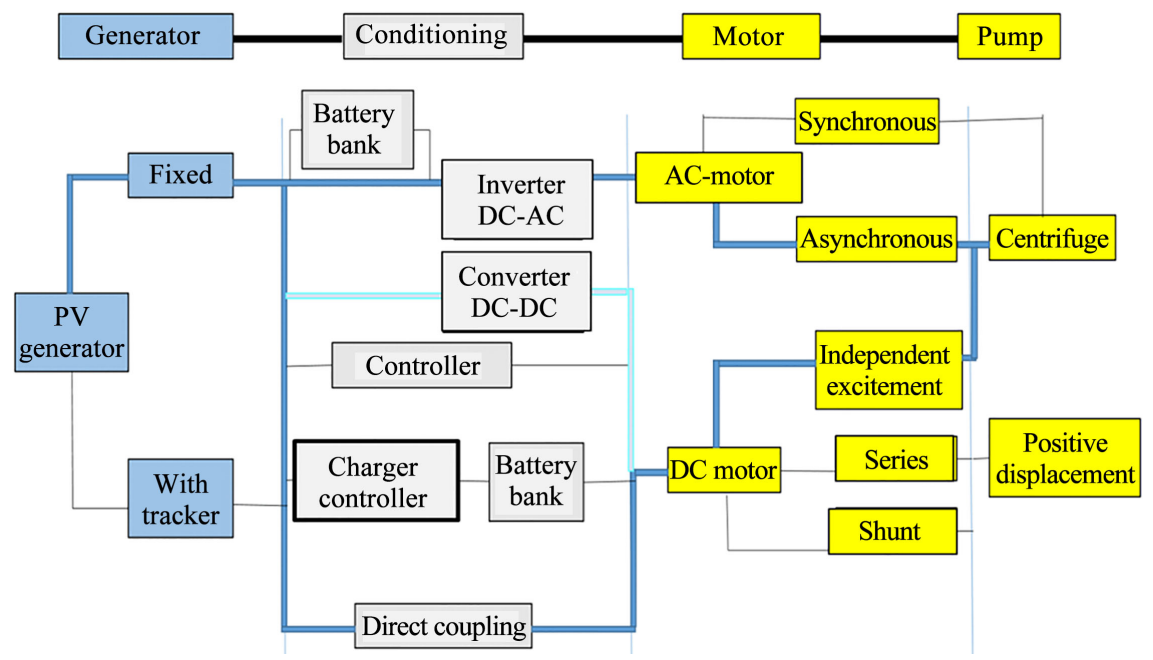

Figure 3. Types of PVWPS configurations: Adapted from [26] [27].

These pumps generally tend to be larger than dynamic pumps of equal capacity. Diaphragm positive displacement pumps (volumetric) are often used for low powers (up to $5 \mathrm{kWp}$ ), or even single or small stage centrifugal pumps, with DC type motors with and without brushes. In cases of higher power, multi-stage and helical positive displacement centrifugal pumps are used [31]. The solar pumps available in the market can pump water from $5 \mathrm{~m}$ to over $200 \mathrm{~m}$ with outputs up to $250 \mathrm{~m}^{3} /$ day, being used in boreholes of 15 to $50 \mathrm{~m}$ of depth [32] [33].

Most of the PVWPS have a water reservoir. The capacity of water reservoir (system autonomy) is determined by the type of supply (domestic, animal, and irrigation) and the financial constraints of the investor. In order to ensure that the water supply service is not impaired during periods of low or absent solar irradiance, the presence of a reservoir is of great importance, and require an analysis of the stochastic nature of the energy resource, flow and periods needs to meet the full demand [34]. However, the water source must recharge the reservoir faster than the water pumping rate, avoiding a reservoir drought as it could damage the pump.

\subsection{Definition and Design of Photovoltaic Water Pumping Systems Parameters}

As seen, the PVWPS have become attractive for livestock and agriculture applications in remote locations with limited access to conventional electricity [35]. In this order it is necessary to define the parameters of the system, even if it is by estimation [36]. Thus, the selection of a pump for PVWPS depends on the following variables that affect the performance of the system and overall system efficiency [37]:

\section{Solar resource:}

- Solar radiation availability,

- Ambient temperature at the location.

Water. 
- Water to be pumped $\left(\mathrm{m}^{3}\right)$,

- Flow rate of water, which is influenced by weather conditions at the location, especially solar irradiance and air temperature variations,

- Size of water storage tank which depends on water to be pumped per day and daily water consumption.

Total Dynamic Head ( TDH):

- Suction head (height from suction point till pump),

- Discharge head (height from pump to storage inlet), and

- Frictional losses.

PV system:

- PV array energy (kWh) and Power (kWp),

- Efficiency of PV technology used.

Pump:

- Pump power $(\mathrm{kW})$,

- Pump efficiency (\%).

The design of a PVWPS generally consists in determining the size of a system that will meet the needs of the user with minimum total investment costs, taking into account technical, economic and social issues, specific to each project. Although, the use of simulation programs allows solving problems of design and optimization PV systems, there are other identified methods such as: intuitive, numerical, analytical and intelligent techniques [38]. In case of autonomous systems, Hahn [39] advises the use of simple arithmetic method whenever the hypotheses are reasonable, based on relation between PV generators, energy accumulator and loads. However, as will be shown in Section 4, other models are also frequent and useful. The respective design procedures are presented in Figure 4.

\section{Determination of the system parameters:}

\section{- Solar Radiation Measurement}

Solar energy is the primary source of all energy sources. Solar radiation reaching the Earth's atmosphere can be decomposed in different ways for analysis purposes. For PV utilization, the most interesting is horizontal global irradiance, which quantifies the irradiance received by a flat horizontal surface $\left[\mathrm{W} / \mathrm{m}^{2}\right]$. It is composed of horizontal diffuse irradiance and direct normal irradiance. The solar radiation is usually measured with the help of a pyranometer that measures the global radiation, while direct radiation can be obtained with a pyrheliometer. The diffuse radiation can be determined by subtracting the measured direct radiation from the global radiation [40].

Studies show that two to three years of local measurement allow estimating the long-term average for global irradiance with an error margin of 5\% [41]. Solar radiation data can also be obtained from databases available on the internet (NasaSSE, NREL, SolarGIS, ESRA, etc.) [42], although it is always preferable to have local measurement campaigns. Data resulting from measurements are reduced to mean values for various time scales (minute, hour, day, and month) and seasonal variabilities. 


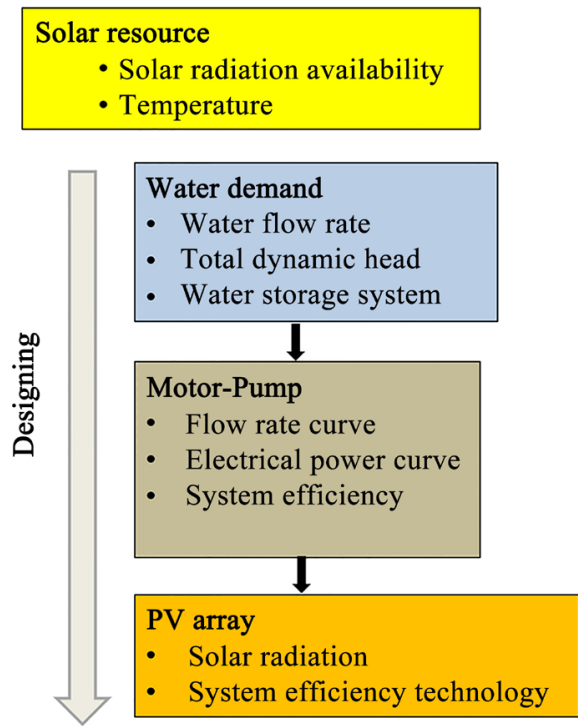

Figure 4. PVWPS design procedures.

\section{- Determination of Hydraulic power}

For determination of water demand, it is necessary to consider the final use of water and/or user requirements. In case of crop irrigation, local and crop specificities must be taken into account. The crop's water demand (net irrigation requirement) depends mainly on the climate, the stage of development, the irrigated area and the efficiency of irrigation.

Valer [43], while reporting the different types of irrigation shows that the irrigation efficiency of micro sprinkler varies from $75 \%$ to $90 \%$, of drip from $85 \%$ to $90 \%$ and for perforated tubes from $65 \%$ to $80 \%$.

For cases in which an exact value of water consumption is not available,

Table 1 provides results illustrating water consumption information by some activities.

Hydraulic power, $\mathrm{P}_{\mathrm{H}}(\mathrm{W})$, required to supply a water flow rate $(\mathrm{Q})$ at a certain $\mathrm{TDH}$, considering the end use of the water and/or user requirements is given by Equation (1):

$$
P_{H}=Q \cdot T D H \cdot \rho \cdot g
$$

where:

- $Q$ is water flow rate $\left(\mathrm{m}^{3} / \mathrm{h}\right)$;

- $T D H$ is the total dynamic head $(\mathrm{m})$;

- $\rho$ is the water density $\left(1000 \mathrm{~kg} / \mathrm{m}^{3}\right.$ at $0^{\circ} \mathrm{C}$ and $\left.1 \mathrm{bar}\right)$;

- $g$ is the acceleration due to gravity $\left(9.81 \mathrm{~m} / \mathrm{s}^{2}\right)$.

In order to calculate the total head, the pressure head and suction head must be considered. Where significant, the pressure drop in piping and connections shall be taken into account. Usually these losses are given by the pipe manufacturers and connections.

However, if the hydraulic power varies from day to day or month to month, etc., due to varying water demand, the PVWPS should be designed for the worst-case combination of solar radiation energy and water demand [46]. 
- Determination of the electric power needs

The electric power to the input of the motor-pump unit, $P_{E L}[\mathrm{~kW}]$, is given by Equation (2):

$$
P_{E L}=\frac{P_{H}}{\eta_{M P}}
$$

where:

- $\eta_{\mathrm{MP}}$ : Efficiency of the motor pump unit;

- Determination of the photovoltaic power needs

A simplified method proposes a simple arithmetic formula that can be used to determine the approximate value of the rated power of the Photovoltaic panel according to Equation (3):

$$
P_{P V}=\frac{P_{E L} \times G_{R E F}}{G_{G l o b} \times F_{Q}}
$$

where:

- $P_{P V}$ is the peak power of the PV array under Standard Test Conditions (STC: radiance $=1000 \mathrm{~W} / \mathrm{m}^{2}, \mathrm{AM} \mathrm{1.5}$, cell temperature $\left.=25^{\circ} \mathrm{C}\right)[\mathrm{kWp}]$,

- $G_{G L O B}$ is the global solar radiance on a horizontal surface $\left[\mathrm{kW} / \mathrm{m}^{2}\right]$,

- $G_{R E F}$ is the incident solar radiance at STC $\left[1 \mathrm{~kW} / \mathrm{m}^{2}\right]$,

- $F_{Q}$ is the quality factor of the system.

In the theoretical limiting case, supply and demand values are equivalent and the quality factor is therefore equal to one $\left(F_{Q}=1\right)$. In the case of measured value, for example, $F_{Q}=0.75$ means that $75 \%$ of the electric power, which is converted from the incident solar power, is used whereas $25 \%$ of the electric energy is lost between the solar cell and the system output or it is not used. This helps to make a decision reasonably on the system type. The quality factors are then given in Table 2.

To obtain the PV system efficiency is used Equation (4):

$$
\eta_{P V}=\frac{P_{P V}}{G_{G L O B} \times A_{\text {array }}} \times 100
$$

where:

$$
A_{\text {array }} \text { area of the PV array }\left[\mathrm{m}^{2}\right] \text {. }
$$

The efficiency of the pumping subsystem $\left(\eta_{M P}\right)$ is defined as the ratio between the output hydraulic power required for lifting a volume of water and the input electric power of the subsystem. The typical efficiency of the motor-pump assemblies in PVWPS is $25 \%$. Table 3 illustrates some values of some motor pump configurations.

The overall solar water pump system efficiency is obtained by Equation (5):

$$
\eta_{\text {total }}=\eta_{P V} \times \eta_{M P}
$$

\section{Overview of Performance Analysis Research of Photovoltaic Water Pumping Systems}

In this section the performance of PVWPS is overviewed along different studies. 
Table 1. Estimated average consumption of water by end use, in liters [44] [45].

\begin{tabular}{cccccc}
\hline $\begin{array}{c}\text { Human }^{2} \\
\text { consumption }\end{array}$ & $\begin{array}{c}\text { Liter/person. } \\
\text { day }\end{array}$ & $\begin{array}{c}\text { Animal } \\
\text { consumption }\end{array}$ & $\begin{array}{c}\text { Liter/animal. } \\
\text { day }\end{array}$ & Cultivation $^{3}$ & Liter/ha.day \\
\hline Survival & 5 & Cattle (milk) & 70 & $\begin{array}{c}\text { Vegetable garden } \\
\text { for subsistence }\end{array}$ & 25.000 \\
$\begin{array}{c}\text { Large urban } \\
\text { centers }\end{array}$ & $10-100$ & Cattle (Cutting) & 40 & Tomato & 46.200 \\
$\begin{array}{c}\text { Small farms } \\
-\end{array}$ & $40-70$ & Sheep/goat & 5 & Corn (maize) & 50.000 \\
& - & Swine & 15 & Bean & 48.000 \\
\hline
\end{tabular}

Table 2. Quality factors of components and different PV systems [47].

\begin{tabular}{cc}
\hline Component/system & $\mathrm{F}_{\mathrm{Q}}$ \\
\hline PV module (crystalline) & $0.85 \ldots 0.95$ \\
PV array & $0.80 \ldots 0.90$ \\
PV system (Grid-connected) & $0.60 \ldots 0.75$ \\
PV system (Stand-alone) & $0.10 \ldots 0.40$ \\
Hybrid system (PV/Diesel) & $0.40 \ldots 0.60$ \\
\hline
\end{tabular}

Table 3. Efficiencies of motor pumps in PVWPS [48].

\begin{tabular}{cc}
\hline Type of motor pump & Efficiency $(\%)$ \\
\hline Surface Centrifuge & $15-25$ \\
Submersible & $25-35$ \\
Positive displacement & $35-45$ \\
\hline
\end{tabular}

Considering the performance and dimensioning parameters for PV systems for water pumping, Odeh et al. [49] carried out a study of a PVWPS with a power of $4.5 \mathrm{kWp}$, in Jordan, activating 3 phases Franklin induction motor coupled to a centrifugal pump and a $55 \mathrm{~m}^{3}$ water storage tank. The main goal was to develop a model that can be used for techno-economic system optimization. The authors identified as performance influencing parameters: the variation of TDH, the amount of fluid extracted, frequency of distribution of irradiance and size of PV modules. For irradiance values ranging from 100 to $500 \mathrm{~W} / \mathrm{m}^{2}$, volumes of 1000 to $3000 \mathrm{l} / \mathrm{h}$ of pumped water were obtained at a fixed head of $24 \mathrm{~m}$. Achieving, PV array, subsystem and system efficiencies respectively of $3.27 \%$, $39.7 \%$ and $3.76 \%$. The techno-economic optimum system configuration is not always the one that gives highest annual system efficiency, it is necessary to take into account the best combinations of slope angles for different seasons throughout the year in irrigation facilities.

\footnotetext{
${ }^{2}$ Adapted from: Comissión Europea DG XII, "Manual de energización rural mediante energia fotovoltaica", 1996.

${ }^{3}$ Adapted from: Organización de las Naciones Unidas para la Agricultura y la Alimentación-"Las necessidades de água de los cultivos"-Caderno Técnico n. 24, 1977.
} 
De Andrade et al. [50] analyzed a PVWPS, with installed power of 15 modules of $75 \mathrm{Wp}$ each, activating a centrifugal pump. The system in question pumped $7900 \mathrm{l} /$ day at manometer height of $35 \mathrm{~m}$ and 12,000 1/day, at manometric height of $18 \mathrm{~m}$. For the same pump under the same operating conditions, the higher the manometer height, the smaller will be the volume of water pumped.

Hamza \& Tiha [51] worked with three submersible pumps, installed at three different locations in Sudan; with solar radiation conditions between 2.9 and 6.5 $\mathrm{kWh} / \mathrm{m}^{2} /$ day. For each of these pumps, solar radiation in the plane of PV array, ambient temperature, PV array voltage and current, water discharge and water delivery pressure were monitored using a datalogger. Pumped water varies from 21 to $38.6 \mathrm{~m}^{3}$ and subsystem efficiency of $30 \%$ and $36 \%$. Solar pumps were found suitable and reliable for supplying water for the Sudan.

Setiawan et al. [52] suggested two important aspects in designing solar water pumping system: 1) analyzing piping system to determine the type of pump used and 2) the power system planning to ensure the system operates properly. The PVWPS will start at level of solar radiation around $300 \mathrm{~W} / \mathrm{m}^{2}$ and is able to lift water to $1400 \mathrm{~m}$. The system uses 32 solar PV panels to produce $3200 \mathrm{Wp}$ maximum power and operates 2 submersible pumps. The flow rate of water produced is about 0.4 to $0.9 \mathrm{l} / \mathrm{s}$.

Abdolzadeh \& Ameri [53] used a positive displacement surface pump with permanent magnet motor, with power $255 \mathrm{Wp}$ and modules of polycrystalline silicon to evaluate pumping profile as a function of solar irradiance. The authors were able to obtain a mean flow rate of $479 \mathrm{l} / \mathrm{h}$ between 8 and $16 \mathrm{~h}$ of the test day, for solar irradiance values ranging from $400 \mathrm{~W} / \mathrm{m}^{2}(8 \mathrm{~h})$ to $1000 \mathrm{~W} / \mathrm{m}^{2}$ $(11.30 \mathrm{~h})$. The PV, subsystem and global efficiencies obtained at TDH of $16 \mathrm{~m}$ are: $9.26 \%, 40.84 \%$ and $3.7 \%$.

Nogueira et al. [54] research addressed PVWPS with monocrystalline and polycrystalline panels, showing that the average daily volume of water pumped by both systems ranged from 3536.461 to $4182.55 \mathrm{l}$, which is enough to meet the basic needs of a small farm in Brazil. The flow of water pumped was more susceptible to voltage variation than to current variation. The polycrystalline system presented higher global efficiency and lower cost per volume of water pumped. Photovoltaic panel efficiency was $9.40 \%$ and $6.57 \%$ for monocrystalline and polycrystalline systems, respectively. As for complete pumping system, the monocrystalline system showed an average global efficiency of $4.27 \%$, whereas the polycrystalline system presented an average global efficiency of $5.00 \%$.

Hamidat [55] presents the electrical and hydraulic performance of a surface centrifugal pump applied to irrigation under Sahara climate conditions. The components are DC/AC inverter and an asynchronous surface motor (750 W) directly coupled to a surface centrifugal pump. The installed power is $1500 \mathrm{Wp}$ for tomato irrigation. The pumped water is $1012 \mathrm{~m}^{3}$ for 135 days whose global efficiency is around $3.8 \%$ and subsystem efficiency varies from $30 \%$ to $35 \%$.

Ghoneim [56] investigated the performance optimization of direct coupled 
photovoltaic powered water pumping system in Kuwait climate. The pumped water was desired to satisfy domestic needs in amount of $12 \mathrm{~m}^{3} /$ day. The monthly demand for water is $360 \mathrm{~m}^{3}$ but the syphilis proposed by Ghoneim monthly pump just over $40 \mathrm{~m}^{3}$ of unnecessary water and Nogueira [57] investigated the performance optimization of photovoltaic powered water pumping to satisfy irrigation needs.

Kolling et al. [58], evaluated the behavior of a PV system of water pumping with direct coupling, under different conditions of solar irradiance and submitted to different manometric heights. The system was composed of DC motor pump, driven by a PV module. The authors concluded that the useful power generated by module and the flow provided by motor pump are directly related to solar irradiance and manometric height. The average daily flow rate ranged from 6.52 to $10.91 \mathrm{l} / \mathrm{min}$.

Benghanem et al. [59], investigated based on the optimal PV array the performance of a directly coupled DC powered PV water pumping system without battery and electronic controls. Four different pumping heads have been tested $(50 \mathrm{~m}, 60 \mathrm{~m}, 70 \mathrm{~m}$ and $80 \mathrm{~m}$ ). The best system efficiency has been obtained for the head of $80 \mathrm{~m}$. The flow rate depends on the pumping head and the global solar irradiation. The motor-pump efficiency did not exceed $30 \%$, which is typical for a directly-coupled photovoltaic pumping system; yet such a system is suitable for low head irrigation in remote areas.

Pande et al. [60] designed and developed a Solar PV pump operated drip irrigation system for growing orchards considering design parameters like pumps size, water requirements, the diurnal variation in the pressure of the pump due to change in irradiance and pressure compensation in the drippers. The system comprises a PV pump with 900Wp PV array and 800W DC motor-pump mono-block, with discharge of $3.8 \mathrm{l} / \mathrm{h}$. The system could irrigate 1 ha area within $2 \mathrm{~h}$.

Yet, in most of the studied systems, the average TDH vary from 2.5 to $250 \mathrm{~m}$. For the Algerian case, TDH vary from $3-40 \mathrm{~m}$ and perfectly adapt to the reality of the water demand for irrigation [61]. When using DC motors coupled to positive displacement pumps, the lower the TDH the greater will be the volume of water pumped. The TDH is directly linked to the volume of water pumped and the type of motor pump used as discussed in Section 2.2.

The most commonly used configuration of PVWPS technology is direct coupling systems with water storage tank, whose water is used for household and irrigation purposes with DC motors coupled to a centrifugal pump for daily demands equal or greater than $10 \mathrm{~m}^{3}$. On the other hand, for lower water demand, DC motors with volumetric pumps are used. It is important to note that DC motors, somehow fit easily into PVWPS, for their compatibility with the power generated by the PV generator. Direct coupling systems studies carried out by Koner [62] indicate that DC motor PVWPS without power condition is superior than AC motor. These systems are simple and reliable used in small-scale 
pumping ( $1 \mathrm{~m}^{3} /$ day to $25 \mathrm{~m}^{3} /$ day) for small irrigations and domestic use. In irrigation area, most of the studied systems have capacity to irrigate areas close to 1ha, which turn the technology in an alternative to supply water for irrigation and domestic use for developing countries as India and Sudan. DC motors with positive displacement pump using only a PV array without battery unit is desirable for socio-economic development in rural communities.

Yet, it is possible to understand, from different authors that the variables that influence the performance of PVWPS are: TDH, quantity of fluid extracted, variation of solar radiation level during a day and season, photovoltaic technology, type of motor pump and voltage variation. From the studies presented on the performance of PVWPS for irrigation, is observable that the different crop water needs and its dynamics along seasons and year are not taken into consideration as a factor that can greatly influence the performance of these systems. In turn, many authors only consider total or daily water demand, not discussing the surplus of the pumped water. The TDH is directly linked to the volume of water pumped and the type of motor pump used, what may presuppose the study of the influence level of TDH on the yield of PVWPS.

From the reviewed articles, it can be observed that the authors are focused largely on technical aspects of the systems and somehow in economic aspects. The social and environmental aspects are not properly exploited in the adoption and design of the PVWPS. Clear studies in these areas can specify how much can be reduced in the emission of harmful gases to the environment and how the involvement of society can contribute positively to increase the useful life of such systems and the development of communities when adopting this technology. All these aspects can contribute to the sustainable development of communities.

The energy efficiency of PV panels production is found to vary from $11 \%$ to $15 \%$ [63]. Despite, the average overall efficiency of studied systems is $4.1 \%$. However, Koner [64] obtained efficiencies ranging from $4.3 \%$ to $4.6 \%$ when assessing the diversity of PVWPS for rural areas. Nevertheless, the PV and overall efficiency of PVWPS do not exceed $10 \%$ and $5 \%$ respectively; this factor must be associated with the number of hours of available sunshine, manufacturing technology of PV panels, methods of conversion, field factors and system design among other factors. Howsoever, it should be noted that the efficiencies obtained through theoretical and experimental cases are approximate, $3.76 \%$ and $3.7 \%$ respectively, which allows saying that optimization models are reliable, although some experimental results showed low global efficiency in the order of $2.3 \%[65]$.

Many studies of the performance of PVWPS and several projects have been carried out in developing countries of Africa, Asia and South America, in experimental form, which make it possible to assert that the technology is technically mature, although it faces some implementation challenges as sustainability.

In grid connected systems, feed-in tariffs are a policy mechanism that provides long-term security to renewable energy producers, typically based on the 
cost of generation of each technology [66]. Technologies such as wind power, for instance, are awarded a lower price per-kWh, while technologies such as solar $\mathrm{PV}$ are offered a higher price, reflecting higher costs [67]. Although in developed countries feed-in tariffs are in disuse, by considering isolated PVWPS as an alternative for developing countries, the price of pumped $\mathrm{m}^{3}$ of water and technology are relevant to the economic feasibility of systems. This fact may lead to try to match the pump functioning to the solar PV peak power and explore the dynamic character of water demand for irrigation purpose.

Generally, the cost of PV largely depends on the government policies, social acceptability, and institutional setup to run the system, and energy demand in specific places. Fiaschi et al. [68] refers that to a $30 \mathrm{~m}^{2} \mathrm{PV}$ system (about 3000 $\mathrm{Wp}$ ) and to a borehole of $100 \mathrm{~m}$, a commercial multi-stage submersible pump lead to a water sale price between 1.23 and $0.67 \$ / \mathrm{m}^{3}$. In turn, Niedzialkoski [69] when discussing the pumped water costs, by a PV system of $150 \mathrm{Wp}$ and a positive displacement surface pump for a TDH of $2.5 \mathrm{~m}$ obtained $0.077^{4} \mathrm{US} \$ / \mathrm{m}^{3}$. The electricity cost generated by solar PV technology varies between 0.13 and 0.17 US $\$ / \mathrm{kWh}[70]$.

Photovoltaic can play an important role in developing countries given the favorable financing terms in order to minimize the annual cost of energy of a particular crop and the access of energy for the community. PVWPS for irrigation will become an increasingly economically advantageous source of electricity over expanding geographical regions [71], considering that in many areas of developing countries there is not access to electricity and PVWPS can be adopted as part of solution. Sorensen et al. [72] points that in India, $1.5 \mathrm{~kW}$ PV panels do not cost more than the cost of any electric line of $1 \mathrm{~km}$. Table 4 resumes the analyzed case studies for site-specific application and performance of PVWPS.

\section{Design Methods of PV Water Pumping Systems}

As seen, proper selection of photovoltaic technology for WPS and its components is essential for the stability and efficiency of the system. In this perspective, in this section, design methodologies used according to the end-use of PVWPS are explored, reviewing different authors in order to identify to what extent the different models of PVWPS design consider the dynamic nature of the water demand of the crops.

Usually, in the sizing of residential PV systems, PVWPS or other, the main efficiency factors are technical, economic and external impacts [73]. The technical factors are related to the system performance, as efficiency, electrical power, TDH, among others. In turn, an economic evaluation of water pumping systems is based on the monetary values of the system, whose most used methods are especially, Net Present Cost (NPC) [74] [75], Life Cycle Cost (LCC) [76], Levelized Cost of Electricity (LCOE) [77], Internal Rate of Return (IRR) and Benefit-to-Cost Ratio (BCR). However, the external impacts evaluation ${ }^{4}$ Source: https://br.investing.com/currencies/brl-usd-converter, accessed at June 8, 2017: R\$ to US\$. 
Table 4. Summary of PV water pumping system performance evaluation studies.

\begin{tabular}{|c|c|c|c|c|c|c|c|c|c|}
\hline Country & $\begin{array}{l}\text { PV power } \\
(\mathrm{Wp})\end{array}$ & Motor pump type & $\begin{array}{l}\text { Head } \\
(\mathrm{m})\end{array}$ & $\begin{array}{l}\text { Type of } \\
\text { system }\end{array}$ & $\begin{array}{c}\mathrm{V} \\
\left(\mathrm{m}^{3} / \text { day }\right)\end{array}$ & $\begin{array}{c}\text { System } \\
\text { efficiency } \\
(\%)\end{array}$ & $\begin{array}{l}\text { Type of } \\
\text { study }\end{array}$ & Application & Author [Ref.] \\
\hline Jordan & 4500 & AC-centrifugal & 24 & PV-*WST & 30 to 100 & 3.76 & Model & N/A & Odeh [49] \\
\hline Brazil & 1100 & DC-Centrifugal & 18 & PV-*WST & 12 & - & $\begin{array}{c}\text { Real } \\
\text { implementation }\end{array}$ & Irrigation & $\begin{array}{c}\text { De Andrande } \\
{[50]}\end{array}$ \\
\hline Sudan & 1100 & $\begin{array}{l}\text { AC-Grundfos } \\
\text { SP4-8 }\end{array}$ & 24 & PV & 32 & 5 & $\begin{array}{c}\text { Real } \\
\text { implementation }\end{array}$ & Irrigation & $\begin{array}{c}\text { Hamza \& Tiha } \\
{[51]}\end{array}$ \\
\hline Indonesia & 3200 & $\begin{array}{c}\text { DC-submersible } \\
\text { Lorentz PS1800 } \\
\text { HR-05 HL }\end{array}$ & 250 & PV-battery & - & - & $\begin{array}{c}\text { Real } \\
\text { implementation }\end{array}$ & Domestic & Setiawan [52] \\
\hline Iran & 250 & $\begin{array}{c}\text { DC-positive } \\
\text { displacement surface }\end{array}$ & 16 & PV-*WST & 3.8 & 3.7 & $\begin{array}{c}\text { Real } \\
\text { implementation }\end{array}$ & N/A & Abdozaldeh [53] \\
\hline Brazil & 150 & $\begin{array}{c}\text { DC-positive } \\
\text { displacement surface }\end{array}$ & 2.5 & PV $-{ }^{\star} W S T$ & 4.2 & 4.27 & $\begin{array}{c}\text { Real } \\
\text { implementation }\end{array}$ & $\begin{array}{c}\text { Irrigation } \\
\left(100 \mathrm{~m}^{2}\right) \text { and } \\
\text { domestic } \\
(\text { small farm })\end{array}$ & Nogueira [54] \\
\hline Algeria & 1500 & $\begin{array}{l}\text { AC-surface } \\
\text { centrifugal }\end{array}$ & 13 & PV-*WST & 1.01 & 3.8 & Model & $\begin{array}{l}\text { Irrigation } \\
(1.49 \mathrm{ha})\end{array}$ & Hamidat [55] \\
\hline Kuwait & 210 & $\begin{array}{l}\text { DC-centrifugal } \\
\text { pump }\end{array}$ & 15 & PV-*WST & 12 & - & Model & $\begin{array}{c}\text { Domestic } \\
\text { (300 persons) }\end{array}$ & Ghoneim [56] \\
\hline Brazil & 710 & - & & PV $-{ }^{*}$ WST & 4.0 & - & $\begin{array}{c}\text { Real } \\
\text { implementation }\end{array}$ & $\begin{array}{l}\text { Irrigation } \\
\text { (1ha) }\end{array}$ & Nogueira [57] \\
\hline Saudi Arabia & 1800 & $\begin{array}{l}\text { DC-submersible } \\
\text { helical pump }\end{array}$ & 80 & PV & N/A & 4.41 & Model & Irrigation & $\begin{array}{c}\text { Benghanem et al. } \\
{[59]}\end{array}$ \\
\hline
\end{tabular}

${ }^{*}$ WST - water storage tank. N/A—not applicable. Real implementation $=$ Experimental study. Model $=$ Theoretical study.

method emphasizes non-monetary values, such as weather, vandalism, that can directly or indirectly affect the selected pumping system [78].

Rawat et al. [79] reviewed the technical and economic processes of designing and optimization techniques of different PV systems configurations. The authors conclude that if the availability of resource data is lower, the intelligent methods are preferable for PV sizing optimization. Furthermore, neural networks, genetic algorithms and fuzzy logic are highly accurate and reliable for sizing optimization but very complex to implement. Though, if long term data is available the numerical method is preferable, being that numerical methods include software and tools which are user friendly. The sizing methods used by the authors focus on the modeling of solar radiation, photovoltaic modules, hydraulic load, insolation and electrical configurations of motor-pumps set.

Gad [80] developed a mathematical model using Matlab software to predict the performance of a direct coupling (12VDC) PV pumping system and a pump controller, in Southern Egypt whose daily water demand was $8 \mathrm{~m}^{3}$, for a total head gauge which varies between $30-40 \mathrm{~m}$, and $300 \mathrm{Wp}$ system power. The model simulates the hourly performance of the system for any day of the year 
and for different orientations of PV-array. Results have shown that the amount of pumped water is of 24.06 (7.77 hrs), 21.47 (6.48 hrs) and 12.12 (4.15 hrs) $\mathrm{m}^{3} /$ day in summer solstice, equinoxes and winter clear sky days respectively for solar irradiation of $500 \mathrm{~W} / \mathrm{m}^{2}$. The calculated PV array efficiency ranges from $13.86 \%$ in winter to $13.91 \%$ in summer. Albeit, the author did not specify the purpose of pumped water, the predicted quantity of pumped water per day is larger than the target value $\left(8 \mathrm{~m}^{3} /\right.$ day) all over the year with a minimum value at December, ranging from 12.12 to $16.4 \mathrm{~m}^{3} /$ day corresponding to operating hours 4.15 and 8.79 per day respectively. The variables considered by the author for the design the system were solar radiation data, optimal PV array tilt angle, PV array and pump.

Ramazan [81] studied a water pump system with mobile PV, for irrigation of $0.5 \mathrm{ha}\left(5000 \mathrm{~m}^{2}\right)$ of apple orchard in Turkey. Irrigation of apple orchard is carried out in the months of May to October, with a daily water demand of 17 $\mathrm{m}^{3} /$ day, being supplied within three days of pumping per week. An angle of $22^{\circ}$ and a power of $460 \mathrm{kWp}$ of PV system, for TDH of $20 \mathrm{~m}$ were considered. The developed mathematical model and simulation shows that it is possible to obtain $21 \mathrm{~m}^{3} /$ day. Nevertheless, the study concluded that the submersible pump should be selected in order to operate with maximum system efficiency considering the latitude of the region, season and effective costs. The costs of irrigation (fuel cost, water cost, and electric costs) reach $30 \%$ of the total gains each year to 18,000 ha. Such costs can be reduced based on the use of mobile PVWPS. The author uses a submersible pump in a mobile system which can compromise the technical quality of the system.

The method of optimal sizing of PVWPS used by Gad and Ramazan can be considered as numerical method. The numerical methods use simulation-based programs for calculating size according to the time interval, usually hourly, considering different parameters. Generally the most used software is PVSYST [82], HOMER [83], Retscreen [84], SAM [85], etc. or in simulation environments are often used MATLAB [86], TRANSYS [87], LABVIEW [88], etc. Yet, Khatib et al. [89], when analyzing different size optimization techniques for PV systems, concluded that simulation based numerical methods are most widely used technique. The intelligent methods use artificial intelligence techniques such as artificial neural network, genetic algorithm, fuzzy logic etc. to solve complicated optimization problem [90].

Concerning intelligent methods, Loxsom \& Durongkaveroj [91] developed and tested an algorithm to estimate the long term monthly performance of a solar photovoltaic water pumping system for irrigation in USA. This methodology uses the standard solar factor correlation equation to calculate the flow rate of a system with an insolation threshold and a pumping rate that has a nonlinear dependence on insolation by using average monthly solar insolation input data and estimated the total monthly volume of water pumped with hourly simulation.

On the other hand, Sinha [92] developed a mixed integer linear model for de- 
termining the cost-effective technology options. The energy required for irrigation is estimated by a mathematical model description. The authors also discuss the techno-economics of different energy resource and technology options for the irrigation sector. The technologies include solar photovoltaic, water pumping windmills, gasifier and biogas plants coupled to diesel engines operating in the dual-fuel mode, electric pump sets, and diesel pumps in the independent mode. The developed model is solved for typical conditions that exist in India.

Considering the reduction of time of return of the isolated PV systems of water pumping Corrêa et al. [93] seeks to extend and validate an alternative to reduce the return time of isolated water pumping PV systems, where it optimizes the efficiency of photovoltaic conversion using maximum power point tracking algorithm, and the losses in the induction motor. For this, an experimental prototype was developed whose results showed a gain of $8 \%$ in the input power.

Khiareddine et al. [94] analyzed a dynamic model for energy control and management in agriculture in Tunisia which consisted of a $1.5 \mathrm{~kW} \mathrm{PV}$ panel, coupled with a 25 Ah acid lead battery, induction motor coupled to centrifugal pump. The simulation based on the Neuro-fuzzy controller showed the effectiveness of the proposed system, and if there is a surplus energy this will be stored in the battery.

Rahrah et al. [95], presents the modeling and design of a photovoltaic system for pumping with batteries. In order for PV generator operate at maximum power point; the authors used three optimization methods: Perturbation and Observation, Fuzzy Logic Controller and Neuro-Fuzzy Algorithm. The simulation was performed based on Matlab/Simulink. As result, the Neuro-Fuzzy algorithm showed better strength through response time.

In addition to the optimal sizing of PVWPS mentioned above, there are other techniques that allow the optimal sizing of PVWPS that adopt various procedures based on the water consumption profiles, total head, tank capacity and photovoltaic array peak power. In this view, Hamidat \& Benyocef [96] used a method of the load losses probability (LLP) to optimize sizing of the PVWPS with a similarity between the storage energy in batteries and water in tanks. The study for small scale of power located in southern Algeria, considered a total head of $20 \mathrm{~m}$, showed that when the LLP varies from 0.01 to 0.1 , the required power of the optimal photovoltaic decreases from 219 to $160 \mathrm{~W}$. For total head of $40 \mathrm{~m}$, the required power of the optimal photovoltaic decreases from 350 to 260 $\mathrm{W}$. This difference of the photovoltaic power (160 and $260 \mathrm{~W})$, required to satisfy the needs, is due to the difference of solar radiation in localities.

The energy produced and the performance of the PV system depends on the number of environmental stochastic parameters which is consequently very important for the optimum reliability, technical efficiency, and cost-effective operation for the selection of best PV configuration for water pumping systems.

Table 5 resumes the analyzed design methodologies of optimal sizing of PV water pumping systems. 
Table 5. Methodology/technique of optimal sizing of PV water pumping systems.

\section{Methodology/technique (Evaluated} variables)

Mathematical model based on Matlab (solar radiation, $\mathrm{PV}$-array, pumped water) (PV-array, efficiency of PV-array, efficiency of overall system)

\author{
Algorithm to estimate the long term \\ monthly performance of a PVWPS \\ (flow rate)
}

Mathematical linear model (for determining the cost-effective technology options and the energy required for irrigation)

Maximum power point tracking induction motor (efficiency of photovoltaic conversion) algorithm and the losses in the

Conclusion

The amount of pumped water is directly proportional to the pumping time for the same solar radiation value.

Submersible pump should be selected in order to operate with maximum system efficiency considering the latitude of the region, season and effective costs. Such costs can be reduced based on the use of mobile PVWPS.

Has a nonlinear dependence on insolation by using average monthly solar insolation input data and estimated the total monthly volume of water pumped with hourly simulation.

The developed model is solved for typical conditions that exist in India, and it is shown that there are conditions in which alternative energy technologies make economic sense.

With the optimization technique developed it was possible to obtain a gain of $8 \%$ in the input power.

Author [Ref.]

Gad [78]

Ramazan [79]

Loxsom \& Durongkaveroj

Sinha $[88]$

If there is a surplus power it can be Neuro-fuzzy controller (energy control stored in the battery which in turn will and management in agriculture) add the power density of the system as a Khiareddine et al. whole.

Perturbation and Observation, Fuzzy Logic Controller and Neuro-Fuzzy Algorithm (time response at maximum power point operation)

The Neuro-Fuzzy algorithm showed better strength through response time Rahrah et al. [91] (4.625 hrs) with efficiency of $79 \%$.

Is possible to use a photovoltaic water pumping system for small-scale

LLP method (electric power of the motor $\left(\mathrm{P}_{\mathrm{m}}\right)$ with volume flow rate and irrigation with an area smaller than 2 ha of crops in Algerian Sahara regions. head)

Regard to the main knowledge of PVWPS models design, four methods can be used: intuitive, analytical, numerical and intelligent, as referenced in Section 2.3.1. The intuitive methods are based on the designer's experience [97], and in this method, simple mathematical equations are used and the estimation is usually oversized [98]. The analytical methods are simple and more accurate, with the support of empirical relationships to calculate the sizing of the components of PV array [99]. These methods employ developed mathematical modeling for design a reliable and/or cost effective PV system [100]. The choice of the appropriate method for the optimum design of the PVWPS depends on the existing variables and the complexity of the system in order to meet the needs of 
the user with minimum total investment costs, taking into account technical, social and environmental issues, specific to each project. Yet, the simulation programs and forecasts are sufficiently precise to performance of solar pumps.

Yet, as research gap, it is possible to understand from different authors that the design methodologies used don't explore the dynamic nature of the end-use of PVWPS. In case of irrigation systems are considered the maximum water demand only, which usually coincides with the flowering season of the crops. Not only, but also of the revised articles in the scope of PVWPS models design used is perceived the little exploration of social aspects, as far as the practices of the farmers in the field in order to develop models as close as possible to the reality of the farmers. Models that are close to the practical reality of farmers can contribute positively to the massive adoption of technology, although the initial investment costs are still relatively high and the environmental benefits will result from good agricultural practices. There is considerable separation between scientists and potential users of the solutions proposed by scientists.

\section{Identifying Photovoltaic Water Pumping Systems Opportunities in Mozambique's Context}

In view of the focus on models of design and performance of PVWPS, the study of renewable and specifically solar energy opportunities in Mozambique gains importance as a way to assess the feasibility of PVWPS implementation in developing countries.

Mozambique is a developing country located on the east coast of Southern Africa, where a large part (68\%) of the population lives in rural areas. Significant part (more of $70 \%$ ) of the population does not have access to the conventional electricity network and only $5 \%$ of the cultivated area is irrigated despite agriculture is accounting for almost 27\% of Mozambique's GDP [101]. Diesel engines still dominate in irrigation sector, since the country suffers from lack of electricity. A gradual change from diesel engines to renewable energy would benefit the economy and the nation as a whole. In turn, photovoltaic water pumping systems for irrigation are being explored since the year 2013. In this context, the use of small and medium scale alternative renewable resources and definition of the policies that govern this strategy are part of the solution to the problems of Mozambique.

Electricity utility in Mozambique, identified the need for an investment of US \$ 2 billion for the period 2011-2021, excluding new plants. However, this investment will reach a coverage of only $44 \%$ of the population [102]. It is clear that conventional electrification cannot satisfy the urgent need for universal access to modern sources of energy, as defended by the United Nations Millennium goals [103], even if investment capital is available.

To disseminate alternative decentralized sources of energy, the Mozambican Government created through the Council of Ministers [104] a resolution establishing the Policy and Tariffs for the Development of New and Renewable Ener- 
gies 2011-2025 [105]. Nonetheless, Mozambique's access to international protocols and agreements also helps on the promotion of renewable energies. The policy developed defines the vision for the energy sector and guides planning for the development of relevant institutions in Mozambique [106], and establishes the role of private sector participation as key to the success of sector development and benefits cooperation.

The Regulation, which sets forth the Tariff Regime for New and Renewable Energies (REFIT), establishes the tariff model for new and renewable energies consisting of a "Renewable Energy Feed-in Tariff", with a view to promote and ensure the diversification of the energy mix and a safe local supply of electricity. These tariffs are applied to the electricity generated by independent producers using renewable energy sources. REFIT divides the tariffs to be applied in the selling of electricity based on respective source and according to generation capacity. Prices vary by technology, being the maximum and minimum limits for solar power plants $0.13 \$ / \mathrm{kWh}$ to $0.22 \$ / \mathrm{kWh}$ and is the highest of all technologies.

According to the National Energy Fund (FUNAE), about 13\% of the population in rural areas has access to electricity through mini-grids or autonomous technologies of renewable energy [107].

Diverse incentives have been given to the promotion of renewable sources of electricity generation and special attention is given by the United Nations [108] to the diversification of the energy matrix, especially in countries where the electricity generation baseload it assured by hydropower plants, which compete directly in what matters to water for electricity generation, human consumption and irrigation.

The Electricity sector in Mozambique depends on $90 \%$ of hydropower $(80 \%$ Zambezi River) [109], a renewable resource, being the rest of the supply complemented by natural gas, coal and other alternative sources of electricity generation. All of these sources have a long-term exploitation and require high costs for the implementation of infrastructure and subsequent exploitation. Although there is a large part guaranteed by renewable sources (around 90\%), there is still difficult access to electricity, and therefore decentralized electricity generation has been adopted in many rural areas. In this context, solar energy has grown to respond different challenges, of which are solar water pumping systems.

In terms of available renewable resources, the country has a diversified spectrum that makes a total of $23.026 \mathrm{GW}$, of which the solar energy source is the most abundant (23.000 GW), followed by hydro (19 GW), wind (5 GW), biomass (2 GW) and geothermal (0.1 GW) [110].

\section{Advancements on Photovoltaic Water Pumping System in Mozambique}

Indeed, the implementation of PVWPS has already began in Mozambique, with some pilot projects, for irrigation and domestic uses purposes, considering the Government and private ONGs efforts. A part of these results was obtained by 
means of duly accredited interviews and studies of internal documents of the institutions in question. Static models based on software of pump manufacturers for PVWPS design are the most widely used in Mozambique by PVWPS traders and government institutions working in this area, because the technology is being explored relatively recently.

In the period between 2006 and 2015, FUNAE [112] installed 58 PVWPS, of which 35 were installed during the year 2015 in Inhambane (20), Zambézia (7) and Manica (8) provinces. In the period from 2007 to 2012, UNIDO ${ }^{5}$ installed PVWPS for irrigation and domestic uses in six villages in the District of Chicualacuala. On average the installed system capacity is $1.280 \mathrm{Wp}$. The Development Cooperation Fund, a Belgian social solidarity organization, in coordination with the Union of Farmers of Manica, also installed an PVWPS in 2011 at the administrative post of Mutefu (Manica Province), which benefits more than 500 families and another in Chimoio (Manica Province) that benefits a cooperative of more than 20 farmers [113]. The Kwaedza Simukai Manica Association (AKSM) has installed five solar systems for community water supply in Manica Province too.

In order to know the pumping profile of some PV systems installed in Mozambique (carried out by FUNAE), and setting the Mozambican scenario regarding PVWPS, Table 6 presents data from some systems that are operational, built between 2005 and 2012 with their technical specifications, such as installed power, well depth and well capacity, defined at the time of installation of the systems.

The majority of PVWPS deployed in Mozambique have been installed for use in small-scale potable water as shows in Figure 5. Because the PVWPS technology is being exploited for less than 10 years, among other government policies, there are no published reports on the performance of the installed systems and the technical, economic, social and environmental evaluation. As referred, the majority of PVWPS were installed with pilot programs, which opens the window for researchers to evaluate the performance of the systems and to suggest models and methods to optimize the performance of systems installed and to be installed. Notwithstanding, it would help to evaluate and improve the overall installed systems performance, based on different mathematical models and simulation programs developed by researchers to predict the performance of PVWPS in developing countries in Africa, Asia, and South America [114].

Yet, the optimization design models for Mozambique can result in the proper selection of components and refinement of PVWPS; however, help in decision making regarding the best configuration of the systems, costs involved, life cycle cost of the systems, technology to use, etc. The role of communities is relevant in order to achieve the useful life of the systems.

The PVWPS enhances the adaptation of green energy while it substantially promotes to mitigate climate change by assuming as estimated that, it may realize

${ }^{5}$ UNIDO (2015). Interview with Jaime Comiche.2 September 2015, Maputo. 
Table 6. PV pumping units in Mozambique [2].

\begin{tabular}{|c|c|c|c|c|}
\hline Project Name & $\begin{array}{l}\text { Water flow } \\
\left(\mathrm{m}^{3} / \text { day }\right)\end{array}$ & TDH (m) & $\begin{array}{l}\text { Power } \\
\left(W_{p}\right)\end{array}$ & End-use \\
\hline Convenience store in Macossa & 5 & 85 & 480 & Human consumption \\
\hline Cheline and Muabsa Electrification & 10 & 45 & 690 & Human consumption \\
\hline Pumping system of Mudaca & 17 & 54 & 600 & Human consumption \\
\hline Pandjane Electrification & 15 & 70 & 900 & Animal consumption \\
\hline Chupanga Electrification & 10 & 33 & 700 & Human consumption \\
\hline $\begin{array}{c}\text { Tinonganine and Djabula } \\
\text { Electrification }\end{array}$ & 10 & - & - & Human consumption \\
\hline
\end{tabular}

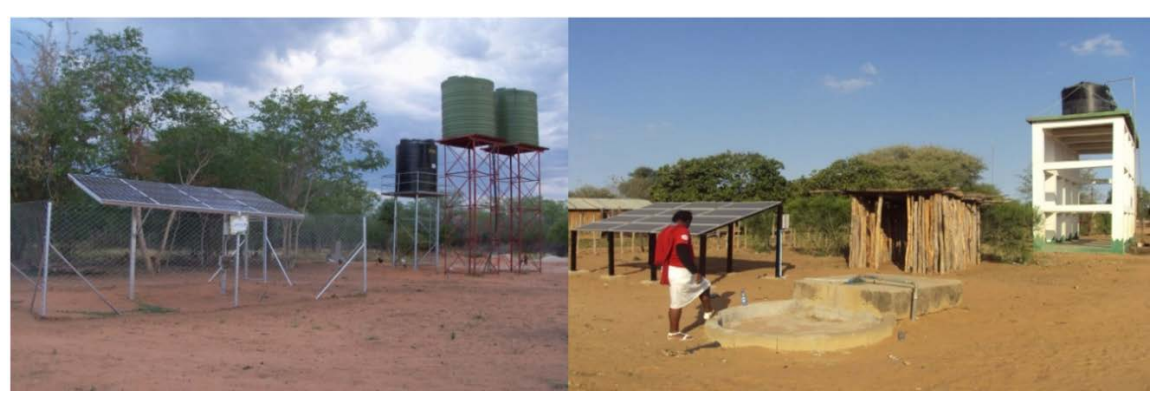

Figure 5. Water pumping stations driven by PV systems for human consumption in Mozambique.

a $\mathrm{CO}_{2}$ reduction of 7.4 ton per ha [115]. In order to enhance the solar irrigation program, in Mozambique, more than 900 PVWPS for irrigation will be installed by the government through the National Irrigation Institute all over the country until 2021. This will be the first major government project in this area.

Mozambique has favorable conditions to enhance the use of PVWPS for various purposes, with regard to available solar radiation levels and definition of strategic policies. However, the PVWPS are not yet a massive solution in part due to high installation costs, weak incentives to popularize PVWPS, weak monitoring of local technicians which operate the systems and a lack of a performance monitoring of the many installed solar pumps accompanied by the vandalism of these systems in the communities.

For the Mozambican case, PV is not yet competitive with grid electricity because the main goal of government is to achieve rural areas without the electricity for lighting [116] and cannot create extra pressure on grid electricity and diesel price. PV systems can be cheaper than grid extension, due to the larger distance between customers and electricity network, highly dispersed population with little energy demand, making national grid extension often economically unreliable. Despite, PV still reveals great advantages in relation to the diesel systems due to fuel cost, fuel availability fluctuation, the difficulties of fuel supply due to the poor state of conservation of the roadways in much of the country, high costs of maintenance and operation, among others.

In the Mozambique perspective, which is the reality of many countries of the 
Austral region of Africa among other developing countries, since PVWPS for human consumption is proven to be a successful experience, the massive use of PV technology for irrigation purpose can play an important role in the development of communities regarding the availability of electricity to the irrigation sector, improvement of the irrigation techniques, increase of food production, contribution for green economy and consequent social and economic improvement as a way to increase the sustainability of developing countries.

\section{Conclusions}

In the present paper, a literature review on the design and performance of PVWPS and Mozambique's perspective on renewable energy technologies was executed. The high number of PVWPS projects carried out in developing countries of Africa, Asia and South America, in experimental and theoretical form, shows that this technology is technically mature.

From the analysis made to the different reviewed authors, in terms of configuration, the most commonly used configuration of PVWPS technology is direct coupling systems without battery storage. These systems are simple and reliable used in small-scale pumping ( $3 \mathrm{~m}^{3} /$ day to $25 \mathrm{~m}^{3} /$ day) for small irrigations and domestic use. In irrigation area, most of the installed systems have capacity to irrigate areas close to $1 \mathrm{ha}$, which turn the technology in an alternative to the continuous and stable production of food and raw materials for the development of communities.

Regarding the parameters of a PVWPS, the variables that influence greatly the performance of the PVWPS are: the amount of fluid extracted, the variation of $\mathrm{TDH}$, technology of photovoltaic modules and the range of solar radiation, which in turn are determinant to the choice of the pumping system technology.

The sizing models of PVWPS can be intuitive, analytical, numerical and intelligent. The choice of the appropriate method depends on the existing variables and the complexity of the system in order to meet the needs of the user with minimum total investment costs, taking into account technical and environmental issues and external impacts, specific to each project. Simulation programs and mathematical models based on the modeling equations, of technical, economic and environmental parameters has been the most used system to obtain the optimum performance of PVWPS. The techno-economic optimum system configuration is not always the one that gives the highest annual system efficiency. Other parameters, like social, must be introduced in order to obtain the best yield of the whole system.

Photovoltaic can play an important role in developing countries given the favorable financing terms and flexibility of technology. PVWPS for irrigation will become an increasingly economically advantageous source of electricity over expanding geographical regions, considering that in many areas of developing countries, there is no access to electricity and PVWPS can be adopted as part of solution for food production increasing, social and economic improvement and contribution for a green economy. 
Different applications lead to conclude that PVWPS are seen as key tool for developing countries, including Mozambique with regard to water provision for irrigation in rural, peri-urban and urban areas, as well as in some areas without access to electricity as an opportunity to make possible access to electricity and to improve the irrigation systems used and life quality. Mozambique is advancing in the definition of concrete policies in the field of renewable energies, mainly in the photovoltaic technology and installation of PVWPS in the pilot phase, which, together with the favorable solar potential, can spark the rapid deployment of communities.

From different authors, it is possible to understand that the design methodologies used do not explore the dynamic nature of the end-use of PVWPS. In case of irrigation systems, they have only considered the maximum water demand, which usually coincides with the flowering season of the crops. The exploration of the dynamic nature of water demand for irrigation can be explored as an alternative energy source in order to minimize the high rates of lack of access to electricity in developing countries. Also, social and environmental aspects are not properly exploited in the adoption of the PVWPS. There is considerable distance between the solutions proposed by scientists for PVWPS and the real needs of potential users of the systems.

\section{Acknowledgements}

Support from Fundação para a Ciência e Tecnologia through grant SFRH/BPD/118076/2016, from IN+ strategic project UID/EEA/50009/201, from the Fundação Calouste Gulbenkian and from Ministry of Science and Technology, Higher Education and Professional Technician of Mozambique, is gratefully acknowledged.

\section{Conflicts of Interest}

The authors declare no conflicts of interest regarding the publication of this paper.

\section{References}

[1] Cabraal, R.A., Kennedy, T.G. and Hoelscher, J. (1991) Photovoltaic-Powered Water Pumping in Mali. European Photovoltaic Solar Energy Conference, Brussels and Luxembourg, 1158-1161. https://doi.org/10.1007/978-94-011-3622-8_296

[2] Funae (2009) Fundo de Energia, Plano Estratégico 2010 -2014. Maputo.

[3] Van Koppen, B., Namara, R. and Safilios, R.C. (2005) Reducing Poverty through Investments in Agricultural Water Management. Part 1. Poverty and Gender Issues. Part 2. Synthesis of Sub-Saharan Africa Case Study Reports. International Water Management Institute, Colombo, $71 \mathrm{p}$.

[4] Campana, P.E., Li, H. and Yan, J. (2013) Dynamic Modelling of a PV Pumping System with Special Consideration on Water Demand. Applied Energy, 112, 635-645.

[5] UNESCO (2012) Ano Internacional da Energia Sustentável para Todos, Escolas de Associação da UNESCO.

[6] Chaurey, A., Sadaphal, P.M. and Yaqi, D. (1993) Experiences with SPV Water 
Pumping Systems for Rural Applications in India. Renewable Energy, 3, 961-964. https://doi.org/10.1016/0960-1481(93)90058-O

[7] Zaki, A.M. and Eskander, M.N. (1996) Matching of Photovolatic Motor-Pump Systems for Maximum Efficiency Operation. Renewable Energy, 7, 279-288. https://doi.org/10.1016/0960-1481(95)00133-6

[8] Fedrizzi, M.C., Ribeiro, F.S. and Zilles, R. (2009) Lessons from Field Experiences with Photovoltaic Pumping Systems in Traditional Communities. Energy for Sustainable Development, 13, 64-70.

[9] Andrade, M.G.D. (2013) Efeito de um sistema de bombeamento de água fotovoltaico na operação de um microaspersor. Master Thesis, Parana, Brazil.

[10] Aler (2016) Energias Renováveis em moçambique-Relatório do Ponto de Situação. ALER-Associação Lusófona de Energias Renováveis.

[11] United States Department of Agriculture (2010) Design of Small Photovoltaic (PV) Solar-Powered Water Pump Systems. Oregon.

[12] Pytlinsk, J.T. (1978) Review Paper Solar Energy Installations for Pumping Irrigation Water. Solar Energy, 21, 255-262. https://doi.org/10.1016/0038-092X(78)90001-4

[13] Kou, Q., Klein, S.A. and Beckman, W.A. (1998) A Method for Estimating the Long-Term Performance of Direct-Coupled PV Pumping Systems. Solar Energy, 64, 33-40. https://doi.org/10.1016/S0038-092X(98)00049-8

[14] Kapadia, K. (2004) Productive Uses of Renewable Energy: A Review of Four Bank-GEF Projects. 1-33.

[15] Katan, R.E., Agelids, V.G. and Nayar, C.V. (1996) Performance Analysis of a Solar Water Pumping System. Proceedings of the 1996 IEEE International Conference on Power Electronics, Drives, and Energy Systems for Industrial Growth (PEDES), New Delhi, 8-11 January 1996, 81-87.

[16] Protogeropoulos, C. and Pearce, S. (2000) Laboratory Evaluation and System Sizing Charts for a "Second Generation" Direct PV-Powered, Low Cost Submersible Solar Pump. Solar Energy, 68, 453-474. https://doi.org/10.1016/S0038-092X(00)00005-0

[17] Chandel, S.S., Naik, M.N. and Chandel, R. (2015) Review of Solar Photovoltaic Water Pumping System Technology for Irrigation and Community Drinking Water Supplies. Renewable and Sustainable Energy Review, 49, 1084-1099. https://doi.org/10.1016/j.rser.2015.04.083

[18] LORENTZ (2017) System Overview. https://pt.scribd.com/document/340502287/Lorentz-Ps2-600-Cs-f

[19] EPIA Photovoltaics and Commission of the European Communities-Directorate General for Energy (2010) Summary Report.

[20] Valer, L.R., Fedrizzi, M.C., Melendez, T.A. and Zilles, R. (2010) Sistemas Fotovoltaicos de Bombeamento para Uso na Agricultura. Universidade de São Paulo, AGRENER, 1-11.

[21] Halcrow, W., et al. (1984) Handbook on Solar Water Pumping: Intermediate Technology Power. UNDP Project GLO/80/003 Executed for the World Bank, Swindon.

[22] Anhalt, J. (1995) Introdução de sistemas de bombas fotovoltaicas-Relatório final sobre a realização de um projeto. GTZ, Fortaleza.

[23] RSP-Regional Solar Programme (1999) Lessons and Perspectives, European Commission (DG VII). Foudation Energies pour le Monde, Bruxelas.

[24] Narvarte, L. and Lorenzo, E. (2010) Sustainability of PV Water Pumping Pro- 
grammes: 12-Years of Successful Experience. Progress in Photovoltaics. Research and Applications, 18, 291-298.

[25] Narvarte, L., Poza, F. and Lorenzo, E. (2006) Specification and Testing of PV Pumps for a Moroccan Project. Progress in Photovoltaics. Research and Applications, 14, 733-741. https://doi.org/10.1002/pip.701

[26] Pinho, J.T. and Galdino, M.A. (2014) Manual de Engenharia para Sistemas Fotovoltaicos. CRESESB/CEPEL, Rio de Janeiro.

[27] Malbranche, P., Servant, J.M., Helm, P. and Haenel, A. (1994) Recent Developments in Photovoltaic Water Pumping Applications and Research in the European Community. 476-481.

[28] Barlow, R., McNelis, B. and Derrick, A. (1993) Solar Pumping.

[29] Hasson, A.M., Al-Sagir, B.E. and Hussein, R. (1990) A Study of Solar Water Pumping Parameters for Baghdad Area. Energy and Environment, 1, 549-556. https://doi.org/10.1016/B978-0-08-037539-7.50094-6

[30] Chandel, S.S., Naika, M.N. and Chandel, R. (2017) Review of Performance Studies of direct Coupled Photovoltaic Water Pumping Systems and Case Study. Renewable and Sustainable Energy Reviews, 76, 163-175. https://doi.org/10.1016/j.rser.2017.03.019

[31] Pinho, J.T. and Galdino, M.A. (2014) Manual de Engenharia para Sistemas Fotovoltaicos. CRESESB/CEPEL, Rio de Janeiro, 1-530.

[32] Kabore, F. (1994) PV Energy for a Sustained and Social Development in the Sahelian Region. 5th Edition, The Regional Solar Program, James and James, London.

[33] Lorenzo, E. (1997) Photovoltaic Rural Electrification. Progress in Photovoltaics. Research and Applications, 5, 23-27. https://doi.org/10.1002/(SICI)1099-159X(199701/02)5:1<3::AID-PIP158>3.0.CO;2$\underline{\mathrm{H}}$

[34] Melendez, T.A.F. (2009) Avaliacao de sistemas fotovoltaicos de bombeamento. Master thesis, Universidade de sao Paulo, Sao Paulo.

[35] New Mexico State University's (NMSU) Department of Engineering Technology (2014) A Solar Choice for Pumping Water in New Mexico for Livestock and Agriculture.

[36] Fedrizzi, M.C. (2003) Sistemas Fotovoltáicos de abastecimento de água para uso comunitário: Lições apreendidas e procedimentos para potencializar sua difusão. Doutorado Programa Interunidades de Pós Graduação em Energia, Universidade de São Paulo.

[37] Argaw, N. and Colorado, D. (2004) Renewable Energy Water Pumping Systems Handbook. NREL Technical Monitor, L. Flowers.

[38] Posadillo, R. and Luque, R.L. (2008) Approaches for Developing a Sizing Method for Stand-Alone PV Systems with Variable Demand. Renewable Energy, 33, 1037-1048. https://doi.org/10.1016/j.renene.2007.06.004

[39] Hahn, A. (1998) Lessons Learned from the International Photovoltaic Pumping Program. 15th European Photovoltaic Solar Energy Conference, Vienna, 2941-2945.

[40] GREENPRO (2004) Energia Fotovoltaica-Manual Sogre Tecnologias, Projectos e Instalação, 1-368.

[41] Empresa de Pesquisa Energética (2012) Análise da Inserção da Geração Solar na Matriz Elétrica Brasileira. Ministério de Minas e Energia, Brasil, 1-64. 
[42] European Commission (2017) Photovoltaic Geographical Information System (PVGIS). http://re.jrc.ec.europa.eu/pvgis/

[43] Morales, L.R.V. (2011) A Utilização de Sistemas Fotovoltáicos de Bombeamento para Irrigação em Pequenas Propriedades Rurais. Master Thesis, Universidade de São Paulo, São Paulo.

[44] Comissión Europea DG XII (1996) Manual de energización rural mediante energia fotovoltaica.

[45] Organizacióon de las Naciones Unidas para la Agricultura y la Alimentación (1977) Las necessidades de água de los cultivos. Caderno Técnico No. 24.

[46] Argaw, N., Foster, R. and Ellis, A. (2017) Renewable Energy for Water Pumping Applications in Rural Villages. http://www.osti.gov/bridge

[47] Photovoltaic Systems Technology (2003) Universität Kassel. Kassel, German.

[48] Sandia National Laboratories (1991) Stand-Alone Photovoltaic System-A Handbook of Recommended Design Practices.

[49] Odeh, I., Yohanis, Y.G. and Norton, B. (2006) Influence of Pumping Head, Insolation and PV Array Size on PV Water Pumping System Performance. Solar Energy, 80, 51-64. https://doi.org/10.1016/j.solener.2005.07.009

[50] de Andrade, E.H.P., Bizerra, L.D.S. and Antunes, F.L.M. (2008) Sistema de Bombeamento de Água com Energia Solar Fotovoltaica Utilizando Motor de Indução Trifásica.

https://pt.scribd.com/document/341282706/Sistema-de-Bombeamento-de-Agua-Co m-Energia-Solar-Fotovoltaica-Utilizando-Motor-de-Inducao-Trifasico

[51] Hamza, A.A. and Taha, A.Z. (1995) Performance of Submersible PV Solar Pumping Systems under Conditions in the Sudan. Renewable Energy, 6, 491-495. https://doi.org/10.1016/0960-1481(95)00049-P

[52] Setiwan, A., Purwanto, D.H., Amuji, D.S. and Urul, H.N. (2014) Development of a Solar Water Pumping System in Karsts Rural Area Tepus, Gunungkidul through Student Community Services. Energy Procedia, 47, 7-14. https://doi.org/10.1016/j.egypro.2014.01.190

[53] Abdolzadeh, M. and Ameri, M. (2009) Improving the Effectiveness of a Photovoltaic Water Pumping System by Spraying Water over the Front of Photovoltaic Cells. Renewable Energy, 34, 91-96. https://doi.org/10.1016/j.renene.2008.03.024

[54] Nogueira, C.E.C., Bedin, J., Niedzialkoski, R.K., Souza, S.N.M. and Neves, J.C.M. (2015) Performance of Monocrystalline and Polycrystalline Solar Panels in a Water Pumping System in Brazil. Renewable and Sustainable Energy Reviews, 51, 1610-1616. https://doi.org/10.1016/j.rser.2015.07.082

[55] Hamidat, A., Benyoucef, P. and Hartani, T. (2003) Small-Scale Irrigation with Photovoltaic Water Pumping System in Sahara Regions. Renewable Energy, 28, 1081-1096. https://doi.org/10.1016/S0960-1481(02)00058-7

[56] Ghoneim, A.A. (2006) Design Optimization of Photovoltaic Powered Water Pumping Systems. Energy Conversion and Management, 47, 1449-1463. https://doi.org/10.1016/j.enconman.2005.08.015

[57] Nogueira, C.U. (2009) Utilização de Sistema Solar e Eólico no Bombeamento de Água para Uso na Irrigação. Mestrado Master Thesis, Universidade Federal de Santa Maria.

[58] Kolling, E.M., de Souza, S.N.M., Ricieri, R.P., Sampaio, S.C. and Dallacort, R. (2004) Análise Operacional de um Sistema Fotovoltáico de Bombeamento de Água. 
Engenharia Agrícola, 24, 527-535.

https://doi.org/10.1590/S0100-69162004000300005

[59] Benghanem, M., Daffallah, K.O., Alamri, S.N. and Joraid, A.A. (2014) Effect of Pumping Head on Solar Water Pumping System. Energy Conversion and Management, 77, 334-339. https://doi.org/10.1016/j.enconman.2013.09.043

[60] Pande, P.C., Singh, A.K., Ansari, S., Vyas, S.K. and Dave, B.K. (2003) Design Development and Testing of a Solar PV Pump Based Drip System for Orchards. Renewable Energy, 28, 385-396.

[61] Hamouda, C., Wagemann, H.G., Hanistch, R. and Siekmann, H.E. (1991) Cost Analysis of Photovoltaic Water Pumping Systems Used in Arid and Semi-Arid Zones in Algeria. In: Luque, A., Sala, G., Palz, W., Dos Santos, G. and Helm, P., Eds., 10th E.C. Photovoltaic Solar Energy Conference, Springer, Dordrecht, 1111-1114.

[62] Koner, P.K., Joshi, J.C. and Chopra, K.L. (1991) A Photovoltaic Water Pumping Testing Facility. RERIC International Energy Journal, 13, 81-97.

[63] N.E.Q.I. Instituto Nacional de Metrologia (2011) Tabela de consumo/Eficiência energética. Componentes fotovoltaicos.

[64] Koner, P.K. (1993) A Review on the Diversity of Photovoltaic Water Pumping Systems. RERIC International Energy Journal, 15, 89-110.

[65] Kolling, E.M. (2001) Análise de um sistema fotovoltaico de bombeamento de água. Dissertaão de Mestrado Master Thesis, Universidade Estadual do Oeste do Paraná.

[66] International Energy Agency-Photovoltaic Power Systems Programme (IEA-PVPS) (2014) Annual Report 2014.

[67] U.S. National Renewable Energy Lab (2017) A Policymaker's Guide Feed-In Tarrif Policies Design. http://www.nrel.gov/docs/fy10osti/44849.pdf

[68] Fiaschi, D., Graniglia, R. and Manfrida, G. (2005) Improving the Effectiveness of Solar Pumping Systems by Using Modular Centrifugal Pumps with Variable Rotational Speed. Solar Energy, 79, 234-244. https://doi.org/10.1016/j.solener.2004.11.005

[69] Niedzialkoski, R.K. (2013) Desempenho de paineis solares mono e policristalinos em um sistema de bombeamento de água. Master Thesis, Universidade Estadual do Oeste do Paraná.

[70] Fantidis, J.G., Bandekas, D.V., Potolias, C. and Vordos, N. (2013) Cost of PV Electricity-Case Study of Greece. Solar Energy, 91, 120-130.

https://doi.org/10.1016/j.solener.2013.02.001

[71] Brankar, K., Pathaka, M.J.M. and Pearce, J.M. (2011) A Review of Solar Photovoltaic Levelized Cost of Electricity. Renewable and Sustainable Energy Reviews, 15, 4470-4482. https://doi.org/10.1016/j.rser.2011.07.104

[72] Sonresen, B., Hummelshoj, R.M. and Mikkelesen, S.E. (1989) Photovoltaic Pilot Project in India. Proceedings of the 9 th ECPVSE Conference, 1054-1056.

[73] Soni, M.S. and Gakkhar, N. (2013) Techno-Economic Parametric Assessment of Solar Power in India: A Survey. Renewable and Sustainable Energy Reviews, 40, 326-334. https://doi.org/10.1016/j.rser.2014.07.175

[74] Kandpal, T.C. and Garg, H.P. (2003) Financial Evaluation of Renewable Energy Technologies. Macmillan India Ltd., Delhi.

[75] Hoppmann, J., Hoffmann, V., Schimidt, T.S. and Volland, J. (2014) The Economic Viability of Battery Storage for Residential Solar Photovoltaic Systems-A Review and a Simulation Model. Renewable and Sustainable Energy Reviews, 39, 1101-1118. https://doi.org/10.1016/j.rser.2014.07.068 
[76] Lazou, A.A. and Papatsoris, A.D. (2000) The Economics of Photovoltaic Stand-Alone Residential Households: A Case Study for Various European and Mediterranean Locations. Solar Energy Materials \& Solar Cells, 62, 411-427. https://doi.org/10.1016/S0927-0248(00)00005-2

[77] Ren, H., Gao, W. and Ruan, Y. (2009) Economic Optimization and Sensitivity Analysis of Photovoltaic System in Residential Buildings. Renewable Energy, 34, 883-889. https://doi.org/10.1016/j.renene.2008.06.011

[78] Argaw, N. (1993) External Impacts Evaluation: An Illustration to Energy Sources Evaluation for Water Pumping Technology. Prepared for the International Conference on Making Sense of Development, Tampere University of Technology, Tampere, Finland.

[79] Rawat, R., Kaushik, S.C. and Lamba, R. (2016) A Review on Modeling, Design Methodology and Size Optimization of Photovoltaic Based Water Pumping, Standalone and Grid Connected System. Renewable and Sustainable Energy Reviews, 57, 1506-1519. https://doi.org/10.1016/j.rser.2015.12.228

[80] Gad, H.E. (2009) Performance Prediction of a Proposed Photovoltaic Water Pumping System at South Sinai, Egypt Climate Conditions. 13th International Water Technology Conference, Hurghada, Egypt, 739-752.

[81] Senol, R. (2012) An Analysis of Solar Energy and Irrigation Systems in Turkey. Energy Policy, 47, 478-486. https://doi.org/10.1016/j.enpol.2012.05.049

[82] PVSYST (2017). http://www.pvsyst.com/en/

[83] HOMER (2017). http://www.homerenergy.com/

[84] RETScreen (2017). http://www.nrcan.gc.ca/energy/software-tools/7465

[85] SAM (2017). https://sam.nrel.gov/

[86] MATLAB (2017). https://www.mathworks.com

[87] TRANSYS (2017). https://sel.me.wisc.edu/trnsys/

[88] LabVIEW (2016). http://www.ni.com/pt-pt/shop/labview/

[89] Khatib, T., Mohamed, A. and Sopian, K. (2013) A Review of Photovoltaic Systems Size Optimization Techniques. Renewable and Sustainable Energy Reviews, 22, 454-465. https://doi.org/10.1016/j.rser.2013.02.023

[90] Hontoria, L., Aguilera, J. and Zufiria, P. (2005) A New Approach for Sizing Stand Alone Photovoltaic Systems Based in Neural Networks. Solar Energy, 78, 313-319. https://doi.org/10.1016/j.solener.2004.08.018

[91] Loxsom, F. and Durongkaveroj, P. (1994) Estimating the Performance of a Photovoltaic Pumping System. Solar Energy, 52, 215-219. https://doi.org/10.1016/0038-092X(94)90071-X

[92] Sinha, C.S. and Kandpal, T.C. (1991) Optimal Mix of Technologies for Rural India: The Irrigation Sector. International Journal of Energy Research, 15, 331-346. https://doi.org/10.1002/er.4440150408

[93] Correa, T.P., Seleme, S.I.J. and Silva, S.R. (2012) Efficiency Optimization in Stand-Alone Photovoltaic Pumping System. Renewable Energy, 41, 220-226. https://doi.org/10.1016/j.renene.2011.10.024

[94] Khiareddine, A., Salah, C.B. and Mimouni, M.F. (2015) Power Management of a Photovoltaic/Battery Pumping System in Agricultural Experiment Station. Solar Energy, 112, 319-338. https://doi.org/10.1016/j.solener.2014.11.020

[95] Rahrah, K., Rekioua, D., Rekioua, T. and Bacha, S. (2015) Photovoltaic Pumping System in Bejaia Climate with Battery Storage. International Journal of Hydrogen Energy, 40, 13665-13675. https://doi.org/10.1016/j.ijhydene.2015.04.048 
[96] Hamidat, A. and Benyoucef, B. (2009) Systematic Procedures for Sizing Photovoltaic Pumping System, Using Water Tank Storage. Energy Policy, 37, 1489-1501. https://doi.org/10.1016/j.enpol.2008.12.014

[97] Sharma, V.K., Colangelo, A. and Spagna, G. (1995) Photovoltaic Technology: Basic Concepts, Sizing of a Stand Alone Photovoltaic System for Domestic Applications and Preliminary Economic Analysis. Energy Conversion and Management, 36, 161-174. https://doi.org/10.1016/0196-8904(94)00065-8

[98] Sidrach de Cardona, M. and Lopez, L.M. (1998) A Simple Model for Sizing Stand Alone Photovoltaic Systems. Solar Energy Materials and Solar Cells, 55, 199-214. https://doi.org/10.1016/S0927-0248(98)00093-2

[99] Barra, L., Catalanotti, S., Fontana, F. and Lavorante, F. (1984) An Analytical Method to Determine the Optimal Size of a Photovoltaic Plant. Solar Energy, 33, 509-514. https://doi.org/10.1016/0038-092X(84)90005-7

[100] Bartoli, B., Cuomo, V., Fontana, F. and Silvestrini, V. (1984) The Design Of photo-Voltaic Plants: An Optimization Procedure. Applied Energy, 18, 37-47. https://doi.org/10.1016/0306-2619(84)90044-8

[101] Banco Espírito Santo (2012) International Support Kit of Opportunities. Research Sectorial, Moçamnique.

[102] EDM (2009) Electricidade de Moçambique. Statistical Reports, 19.

[103] United Nations (2016) The Sustainable Development Goals Report. New York.

[104] B.R.-Imprensa Nacional de Moçambique (2011) Boletim da República. Série número 41.

[105] INTELLICA (2015) Estratégia para o envolvimento do sector privado na electrificação rural e acesso à energia renovável em Moçambique.

[106] PNDENR (2009) República de Moçambique, Política de Desenvolvimento de Energias Novas e Renováveis (B.R. no 41, Conselho de Ministros, Resolução 62/2009).

[107] Artur, F., Soliano, O. and Mariezcurrena, V. (2011) Estudo de Avaliação de energias Renováveis em Moçambique. Relatório Final de Consultoria.

[108] UNRIC (2016) Guia Sobre Desenvolvimento Sustentável. 17 Objectivos para Transformar o Nosso Mundo.

[109] NIPPON KOEI UK (2012) Estudo do Impacto Sócio-Ambiental. Projecto Cahora Bassa Central Norte.

[110] FUNAE (2013) Atlas das Energias Renováveis de Moçambique.

[111] FUNAE (2015) Brochura da Fábrica dos Painéis Solares. http://www.funae.co.mz/index.php/pt/?option=com_sppagebuilder\&view=page\&id $=15$

[112] FUNAE (2015) Relatório do FUNAE 1997-2014.

[113] GreenLight. (2015) Avaliação externa dos projectos de energia renovável.

[114] Sontake, V.C. and Kamamkar, V.R. (2016) Solar Photovoltaic Water Pumping System-A Comprehensive Review. Renewable and Sustainable Energy Reviews, 59, 1038-1067. https://doi.org/10.1016/j.rser.2016.01.021

[115] Campana, P.E., Li, H., Zhang, J., Zhang, R., Liu, J. and Yan, J. (2015) Economic Optimization of Photovoltaic Water Pumping Systems for Irrigation. Energy Conversion and Management, 95, 32-41. https://doi.org/10.1016/j.enconman.2015.01.066

[116] República de Moçambique (2015) Programa Quinquenal do Governo 2015-2019. Maputo. 